new laws should be made technologically neutral. It is this approach that will ensure the necessary stability of legal regulation in the conditions of rapid changes in technological reality.

The significance of the global problem becomes a matter of legal safeguards for the effective development of the informational environment. Huge amounts of information accumulated by humanity in the process of life will obviously require new legal mechanisms. Existing rights to ownership of information and intellectual property rights are likely to be supplemented by new institutions resembling the right to use subsoil and the right to archaeological activity. The set of these issues should be considered as the establishment of a coordinate system for the future legal assessment of both artificial intelligence and technologically advanced people, since it is precisely in this area that the overwhelming part of their socially significant activity will take place.

Key words: law, transhumanism, artificial intelligence, technological neutrality, informational environment. правових дисииплін Луганського державного університету внутрішніх справ імені Е.О. Дідоренка (м. Сєвєродонецььк, Украӥна)

\title{
ПРАВОВІ АСПЕКТИ ВИЗНАЧЕННЯ СТАТУСУ ВІЙСЬКОВОПОЛОНЕНОГО З ОГЛЯДУ НА ПРОВЕДЕННЯ УКРАЇНОЮ ОПЕРАЩЇ̈ ОБ'ЄДНАНИХ СИЛ (АТО) ІЗ ЗАБЕЗПЕЧЕННЯ НАЦІОНАЛЬНОЇ БЕЗПЕКИ І ОБОРОНИ, ВІДСІЧІ ТА СТРИМУВАННЯ ЗБРОЙНОЇ АГРЕСІЇ РФ У ДОНЕЦЬКІЙ I ЛУГАНСЬКІЙ ОБЛАСТЯХ
}

У статті надано міжнародно-правову характеристику понять «комбатант», «некомбатант», «цивільна особа», «жертви війни», «військовополонений», «цивільний заручник» 3 огляду на норми міжнародного гуманітарного права, а також їх порівняльну характеристику з поняттям фізичних осіб, які, перебуваючи на законних підставах на території України, були захоплені в заручники або в інший спосіб незаконно позбавлені волі, який застосовується в законодавстві України. Вивчено питання потреби нормативного закріплення поняття «військовополонений» у нормативно-правових актах України в контексті проведення нею операції Об'єднаних Сил (АТО) із забезпечення національної безпеки і оборони на Сході України.

Ключові слова: збройний конфлікт, гібридна війна, комбатант, некомбатант, цивільна особа, жертви війни, військовополонений, цивільний заручник, антитерористична операція (АТО), операція Об'єднаних Сил (ООС).

Постановка проблеми. Попри всі зусилля міжнародної спільноти забезпечити мир, війни та збройні конфлікти, на жаль, є ознакою нашого сьогодення, а проблеми гуманного ставлення до людини та концепції «людиноцентризму» стають украй актуальними саме під час цих страшних та небезпечних явищ. Для України - це кривавий збройний конфлікт у їі східних регіонах. 
Згідно $з$ повідомленням офісу ООН з координації гуманітарних питань (UNOCHA) понад 2540 цивільних осіб загинули та 9000 отримали поранення після початку бойових дій на Сході України, а 3,4 млн осіб терміново потребують гуманітарної допомоги та захисту [1].

Точна кількість осіб, які знаходяться в полоні або в заручниках, є невизначеною; за різними даними це може бути від 112 до 1200 осіб. Скажімо, за даними Антитерористичного центру Служби безпеки України на кінець 2018 року знайдено і звільнено 3088 осіб, до того ж на тимчасово непідконтрольних Україні територіях Донбасу залишаються в заручниках (військовому полоні) 112 осіб, а 490 вважаються зниклими безвісти, але за інформацією представника України в гуманітарній групі 3 урегулювання ситуації на Донбасі таких установлених осіб - 55. За іншими даними, у полоні на Донбасі знаходиться 102 українських полонених, з них 13 - військових та 89 - цивільних [2].

Водночас постає не проста принципова проблема щодо визначення правового статусу зазначених осіб, який безпосередньо впливає на умови їхнього утримання, доступу до них представників міжнародних правозахисних організацій, рівень та ефективність їхньої правової захищеності в Україні тощо.

Згідно 3 чинним $[3$, с. 1$],[4$, с. 6], [5, с. 2] і перспективним $[6$, с. 1] законодавством України в ситуації на Сході України «військовополонені» відсутні, що відповідно до статей 9, 18, 85 Конституції України [7] та ч. 2 ст. 19 Закону України «Про міжнародні договори» [8] суперечить нормам міжнародних договорів, про обов'язковість яких заявлено Верховною Радою України, а саме Женевським конвенціям [9, с. 2, 4] та [10, с. 4, 34].

Водночас саме в положеннях Женевських конвенцій 1949 року та додаткових протоколах до них визначено правові статуси «військовополонених» та «цивільних заручників», закріплено загальні правові гарантії стосовно цих категорій жертв війни.

Актуалізується тема запропонованого дослідження через продовження, так званої, «гібридної війни», що відбувається на Сході України, і з огляду на відверто затяжний іï характер.

Аналіз останніх досліджень і публікацій. Теоретичною основою дослідження стали праці вітчизняних і зарубіжних учених, які розробляли проблематику теорії міжнародного гуманітарного права та правового статусу військовополонених, серед яких: В. Ф. Антипенко, І. М. Арцибасов, Б. В. Бабін, М. В. Буроменський, О. В. Буткевичі, Ф. Бюньон, В. А. Василенко, О. О. Вовк, М. М. Гнатовський, О. О. Гріненко, М. В. Грушко, Е. Давид, В. Н. Денисов, А. І. Дмитрієв, Н. В. Дрьоміна-Волок, К. Дьорман, О. В. Срохіна, Г. В. Ігнатенко, Ю. Д. Ільїн, Н. В. Калкутінова, А. Я. Капустін, В. О. Карташкін, О. В. Київець, Ю. М. Колосов, Т. Р. Короткий, О. П. Коротков, В. М. Лисик, I. І. Лукашук, Ф. Ф. Мартенс, О. О. Мережко і А. В. Мінаєви, Я. Ю. Миколаєнко,

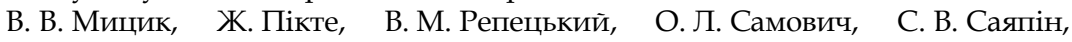
Л. Д. Тимченко, О. І. Тіунов, Г. І. Трофанчук, С. Л.Чумарьов, Х. П. Ярмакі та багато інших. 
Утім, питання статусу військовополонених досліджувалися тільки 3 огляду (у ракурсі та ретроспективі) різних історичних епох і минулих війн, без урахування сучасних реалій щодо, так званих, гібридних війн та збройних конфліктів, охоплюючи трагічні події на Сході України.

Наукова новизна теми статті полягає в тому, що питання національного та міжнародно-правового режиму військовополонених в умовах, так званої, «гібридної війни» на Сході України, на жаль, не стали об'єктом ретельного дослідження вчених-юристів, хоча це стосується багатьох наших співвітчизників, які опинилися проти своєї волі у військовому полоні.

Формування цілей. Метою статті $є$ встановлення можливості застосування до громадян України, які брали (беруть) участь у захисті територіальної цілісності держави на іiі сході, та які утримуються (утримувались) в полоні (заручниках), норм міжнародного права щодо статусу військовополонених та закріплення цих норм у національних нормативно-правових актах.

Виклад основного матеріалу. Зауважимо, що як би не розглядалася на офіційному рівні сучасна ситуація на Сході України, який би правовий термін для її визначення не вживався, це все одно війна - збройний конфлікт у розумінні міжнародного гуманітарного права. Зазначене опосередковано визнається в аб. 7 преамбули Закону України «Про особливості державної політики із забезпечення державного суверенітету України на тимчасово окупованих територіях Донецької та Луганської областях», де констатується, що одним із наслідків збройної агресії Російської Федерації проти України стала тимчасова окупація частини території України, саме 3 огляду на положення відповідних норм міжнародного гуманітарного права [4].

Водночас згідно з нормативно-правовими актами України полонені, у ситуації на Сході України, відсутні. Зокрема, з початком оголошення проведення антитерористичної операції (далі - АТО), у дальшому - операції Об'єднаних Сил із забезпечення національної безпеки і оборони, відсічі та стримування збройної агресії Російської Федерації у Донецькій і Луганській областях (далі - ООС), відповідно та в межах зазначених правових режимів заявляється, що в Україні немає військовополонених, а є заручники, які захоплені i/або утримуються саме терористами самопроголошених республік, а не представниками окупаційної адміністрації, для спонукання державного органу, підприємства, установи чи організації або окремих осіб здійснити якусь дію або утриматися від здійснення якоїсь дії як умови звільнення особи, яка захоплена і/або утримується [3, с. 1].

Крім цього, згідно з чинним законодавством України ці особи вважаються або «незаконно затримані, утримувані громадяни України» $[4$, c. 6]; або «особами, яких було незаконно позбавлено особис тої свободи внаслідок дій незаконних збройних формувань та/або органів влади Російської Федерації на окремих територіях Донецької та Луганської областей, де органи державної влади тимчасово не здійснюють свої повноваження, та тимчасово окупованій території України» [5, с. 2]; або «фізичними особами, які, перебуваючи на законних підставах на території 
України, були захоплені в заручники або були в інший спосіб незаконно позбавлені волі» [6, с. 1].

Але в наслідок цього особи, які брали (беруть) участь у ATO (ООС), які входили(ять) до складу Збройних сил України (включаючи особовий склад ополчення і добровольчих загонів, що входять і не входять до складу збройних сил) як воюючої сторони (антитерористичних або об'єднаних сил), які безпосередньо ведуть бойові дії проти супротивника зі зброєю в руках та отримують відповідний статус учасника бойових дій, нормативно-правовими актами України прирівнюються до цивільного населення під час війни (збройного конфлікту) та юридично виводяться 3-під дії багатьох міжнародних договорів, учасниками яких є сама України та на які сама ж і посилається в зазначеній преамбулі закону, а саме: ст. 4 Положення про закони і звичаї війни на суходолі Додатку до IV Гаазької конвенції про закони і звичаї війни на суходолі від 18.10 .1907 [11, с. 4]; статті 43-45 Додаткового протоколу до Женевських конвенцій від 12.08.1949, що стосується захисту жертв міжнародних збройних конфліктів (Протокол I), від 08.06.1977 [12, с. 43-45]; та на яку, на жаль, не посилається - ст. 4 Женевської конвенції про поводження 3 військовополоненими від 12.08.1949, ратифікованої Україною 03.07.1954 [9, с. 4].

Проте цивільне населення складається з усіх осіб, які є цивільними особами, тобто, будь-яких осіб, які не належать до комбатантів (від фр. Combatant - «воїн», «той, хто воює») та некомбатантів (від фр. Noncombattants - «той, хто не воює») [12, с. 50].

Поліція, міліція та інші воєнізовані організації (напіввоєнні організації або озброєні організації, що забезпечують охорону порядку) можуть бути прирівняні до збройних сил за умови, що сторона, яка ввела їх до складу збройних сил, оголосить про це всім іншим сторонам конфлікту. При невиконанні такої умови членів особового складу цих сил розглядатимуть як цивільних осіб [12, с. 43]. Відповідна заява Україною зроблена, за якою працівники правоохоронних органів та інші особи, які залучаються до здійснення заходів із забезпечення національної безпеки і оборони, відсічі і стримування збройної агресії Російської Федерації у Донецькій та Луганській областях, на час проведення таких заходів підпорядковуються Командувачеві об'єднаних сил, рішення якого є обов'язковими до виконання [4, с. 9].

Навіть без огляду на моральну оцінку визначення статусу осіб, які належать(належали) до складу Збройних сил України (антитерористичних або об'єднаних сил), які зі зброєю в руках безпосередньо беруть (брали) участь у воєнних діях проти супротивника із захисту держави, виконуючи накази ії керівництва, та яких було захоплено в полон як осіб, «яких було незаконно позбавлено особистої свободи внаслідок дій незаконних збройних формувань та/або органів влади Російської Федерації на окремих територіях Донецької та Луганської областей, де органи державної влади тимчасово не здійснюють свої повноваження, та тимчасово окупованій території України», можна констатувати, що за нормами національних нормативно-правових актів усі громадяни України, які утримуються на непідконтрольній Україні території, зокрема й захоплених у полон, є не 
більше ніж потерпілі від злочинних дій незаконних збройних формувань, та не вважаються, виходячи 3 норм міжнародного гуманітарного права, захопленими внаслідок збройної агресії та (або) агресивних дій РФ, тобто «військовополоненими».

Саме через підміну понять зазначені особи не можуть мати жодного окремого статусу - «військовополонений» або «цивільний заручник» - (у разі захоплення не через перебування у складі Збройних сил України), який має принципове значення для положення та утримання самих захоплених (полонений, незаконно позбавлений особистої свободи, заручник тощо).

Водночас особи, які входять до складу збройних сил сторони, і які перебувають в конфлікті, що складаються з усіх організованих збройних сил, груп і підрозділів, та перебувають під командуванням особи, відповідальної перед цією стороною за поведінку своїх підлеглих, навіть якщо ця сторона представлена урядом чи владою, не визнаними супротивною стороною (крім інтендантського, юридичного, медичного і духовного персоналу, який належить до некомбатантів), є комбатантами, тобто вони мають право брати безпосередню участь у воєнних діях. Будь-який комбатант чи некомбатант, який бере участь у воєнних діях і потрапляє під владу супротивної сторони, вважається військовополоненим і саме тому користується захистом III Женевської конвенції про поводження 3 військовополоненими та IV Гаазької конвенції про закони і звичаї війни на суходолі $[12$, с. $43-45 ; 11$, с. 3$]$.

Крім цього, для сприяння посиленню захисту саме цивільного населення від наслідків воєнних дій комбатанти зобов'язані відрізняти себе від цивільного населення (мати особу, відповідальну за своїх підлеглих; певний і виразно видимий здалека відмітний знак; відкрито носити зброю; дотримуватися у своїх діях законів і звичаїв війни тощо) [12, с. 44].

Навіть більше, за нормами міжнародного права захоплення в полон під час воєнних дій не вважається протиправними діями, а лише правом збройних сил сторони, яка перебуває у збройному конфлікті, але до того ж, за будь-яких обставин, з суворим дотриманням норм щодо поводження 3 полоненими (гуманно, без будь-якої дискримінації за ознаками раси, кольору шкіри, релігії чи вірування, статі, походження чи майнового становища, чи будь-якими іншими аналогічними критеріями) $[9$, с. 3; 11, с. 3, 7].

Військовополоненими в розумінні III Женевської конвенції, є особи, які потрапили в полон до супротивника й належать передусім до однієї з таких категорій: особового складу збройних сил сторони конфлікту; членів ополчення або добровольчих загонів, які є частиною цих збройних сил; членів організованих рухів опору [9, с. 4].

Але навіть якщо Україна не визнає за захопленими в полон учасниками ООС (АТО) статус «військовополонених», не вважаючи їх комбатантами, то 3 огляду на ст. 3 Положення про закони і звичаї війни на суходолі Додатку до IV Гаагської Конвенції про закони і звичаї війни на суходолі (набрала чинності для України 24.08.1991) у разі захоплення ворогом як комбатанти, так і некомбатанти користуються правами військовополонених [11, с. 3]. 
3 огляду на зазначене та правила ст. 50 Додаткового протоколу до Женевських конвенцій, що стосується захисту жертв міжнародних збройних конфліктів [12, с. 50], особи, які брали (беруть) участь у АТО (ООС) зі зброєю та отримують відповідний статус учасника бойових дій, не можуть вважатися цивільними особами, які знаходяться під захистом лише Женевської конвенції про захист цивільного населення під час війни, ураховуючи випадки захоплення їх у полон.

На сьогодні статус осіб, які беруть/брали безпосередню участь у виконанні бойових завдань під час захисту державного суверенітету, територіальної цілісності та інших національних інтересів України в складі військових та добровольчих формувань України як військовослужбовці (резервісти, військовозобов'язані) Збройних сил України, Національної гвардії України, Служби безпеки України, Служби зовнішньої розвідки України, Державної прикордонної служби України, Державної спеціальної служби транспорту, поліцейські, особи рядового, начальницького складу, військовослужбовці Міністерства внутрішніх справ України, Управління державної охорони України, Державної служби спеціального зв'язку та захисту інформації України, Державної служби України 3 надзвичайних ситуацій, Державної пенітенціарної служби України, інших утворених відповідно до законів України військових формувань передбачено лише нормами спеціального законодавства щодо державної політики із забезпечення державного суверенітету України у зв' язку з подіями на Сході України, та позбавляе їх права вважатися комбатантами чи некомбатантами, які потрапили під владу супротивної сторони, тобто вважатися військовополоненим у розумінні норм міжнародного гуманітарного права, 3 усіма наслідками та відносними перевагами цього статусу.

Скажімо, відповідно до ст. 60 III Женевської конвенції про поводження з військовополоненими держава, що тримає в полоні, має виплачувати всім військовополоненим щомісячний аванс грошового забезпечення, розмір якого встановлюється конвертацією у валюту зазначеної держави (рублі РФ) сум у розмірі від восьми до сімдесяти п'яти швейцарських франків (майже збігається з курсом долара США), що залежить від категорії військовослужбовців ( від рядового до генерала).

Якщо Україна визнає зазначений за цими особами статус «військовополоненого», виходячи зі змісту статей 66, 68 зазначеної Конвенції, ці гроші можна в безспірному порядку вимагати від іншої сторони збройного конфлікту як самим звільненим або репатрійованим військовополоненим, так і відповідним державним органам України [9, с. 60, 66, 68].

Навіть більше, з огляду на те, що військовополонені перебувають у руках ворожої держави, а не окремих осіб чи військових частин, які взяли їх у полон, визнаючи за захопленими цей правовий статус, Україна може вимагати від цієї держави утримання цих осіб до їхнього визволення 3 полону у відповідних таборах або приміщеннях, розміщених у зонах, що знаходяться на достатній відстані від зон бойових дій, для того, щоб вони перебували в безпеці, а не у в'язницях і тюрмах для засуджених злочинців 
(пенітенціарних установах) у безпосередній зоні бойових зіткнень, як це, на жаль, відбувається із захопленими учасниками ООС (АТО) [9, с. 12, 19, 97].

Зауважимо, що воююча сторона збройного конфлікту, яка порушує норми гуманітарного права, підлягає відповідальності у формі відшкодування збитків, якщо для цього є підстави, та є відповідальною за всі діï, учинені особами, які входять до складу їі збройних сил [11, с. 3].

Про доречність і необхідність застосування в Україні саме термінології міжнародного гуманітарного права свідчать правила ст. 2 III Женевської конвенції, за якими «крім положень, які виконуються в мирний час, ця Конвенція застосовується в усіх випадках оголошеної війни чи будь-якого іншого збройного конфлікту, що може виникнути між двома чи більше ऑї учасниками, навіть якщо стан війни не визнаний однією з них. Конвенція також застосовується в усіх випадках часткової або повної окупації території держави-учасниці, навіть якщо цій окупації не чиниться жодний збройний опір» [9, с. 2], як це відбувається у відносинах України та РФ через події на Сході України. До того ж, як убачається, є непринциповим, який саме термін вживається для характеристики зазначеного збройного конфлікту з погляду міжнародного гуманітарного права.

Послідовно та безумовно визнаючи за захопленими учасниками ООС (ATO) статус військовополоненого, через державу-покровительку, Центральне агентство у справах військовополонених або інші міжнародні організації передусім Міжнародний комітет Червоного Хреста, можна запобігти серйозним порушенням стосовно цих осіб, також їх майна, які користуються захистом III Женевської конвенції, а саме: умисного вбивства, тортур або нелюдського поводження, зокрема біологічних експериментів, умисного заподіяння тяжких страждань або серйозного тілесного ушкодження, або шкоди здоров'ю, примушування військовополоненого до служби в збройних силах ворожої держави, або умисного позбавлення його прав на справедливе та належне судове розслідування, передбачених цією Конвенцією [9, с. 130].

Існує багато підходів до розуміння новітніх феноменів у практиці сучасних міжнародних відносин щодо збройних конфліктів: «гібридна загроза», «гібридна війна», «гібридний конфлікт». Водночас, на думку автора, відсутність міжнародно-правового понятійно-категоріального апарату щодо цих явищ в умовах прямої чи непрямої збройної агресії РФ у ситуації з Автономною Республікою Крим (далі - АРК) та на Сході України не $є$ визначальною.

Усі війни та збройні конфлікти, принаймні за останні 200 років (починаючи 3 Наполеонівських війн), можна обгрунтовано вважати «гібридними» саме через те, що вони поєднували як традиційні, так i нетрадиційні (зокрема відверто терористичні) методи та засоби ведення війни з використанням новітніх, на конкретний час, видів озброєнь і більш високих інформаційних технологій i засобів щодо дезорганізації та деморалізації військових формувань і населення країн-противників чи їх союзів для отримання військово-політичної перемоги над ними або політичної, економічної та соціальної дестабілізації в них. 
Для правової кваліфікації та практичного застосування законодавства щодо правового статусу комбатантів (некомбатантів), які опинилися в полоні внаслідок війни чи міжнародного конфлікту, убачається доцільною правова позиція, згідно 3 якою поняття «війна» та «збройний конфлікт» $\epsilon$ вирішальними, а які саме вони - «гібридні» чи «традиційні», в умовах прямої чи непрямої збройної агресії, не є принциповим, а тому не є визначальним.

Водночас не можна не погодитися з Г. Динис, який вважає, що чинні норми міжнародних конвенцій і принципи сучасного міжнародного гуманітарного права не відображають новітніх трансформацій природи сучасних міждержавних збройних конфліктів 3 наявними елементами гібридних військових дій [13].

Але на наш погляд, усі дискусії щодо гібридності війни в АРК і Донбасі, з огляду на забезпечення прав військовополонених як жертв війни, не мають практичного значення, оскільки міжнародно-правова кваліфікація, яка сформована сучасними універсальними принципами міжнародного права та міжнародним гуманітарним правом, дає достатній правовий інструментарій для формулювання вичерпних правових оцінок збройному конфлікту на Донбасі та подіям навколо АРК. Зокрема, зазначені трагічні події є збройним конфліктом у розумінні міжнародного права і саме через загальні правові засади маємо визначати статус жертв війни, охопно зі статусом «військовополонених».

Навіть більше, норми міжнародного гуманітарного права не вимагають від України формального визнання зазначених осіб «військовополоненими» чи «цивільними заручниками», досить наявності самих обставин їхнього захоплення на сході нашої держави під час збройного конфлікту. До того ж важливо лише, як сама Україна з правового погляду сприймає цих осіб, тобто як визначає на національному рівні їхній правовий статус, чи дотримується та забезпечує гарантії їхнього правового і соціального захисту та відповідної реабілітації відповідно до цього статусу.

3 огляду на проголошення в Україні примату норм міжнародного права [7, с. 9; 8, с. 19], але за відсутності спеціального правового регулювання всередині держави, міжнародні принципи та норми міжнародного гуманітарного права щодо статусу захоплених у полон комбатантів на території України залишаються такими, що не реалізовуються.

Утім, як свідчать події навколо зазначеного збройного конфлікту, захоплені в полон комбатанти, крім тих, які добровільно здалися в полон через боягузтво або легкодухість [14, с. 430], можуть знаходитися під владою супротивної сторони дуже тривалий час, навіть роками. Це роки життя конкретної людини, упродовж яких з нею можуть відбуватися різні події.

За нормами міжнародного права військовополонені підпорядковуються законам, статутам і наказам, які є чинними у збройних силах держави, що тримає в полоні, а це $є$ виправдано в уживанні юридичних або дисциплінарних заходів стосовно будь-якого скоєного військовополоненим порушення. Якщо будь-який закон, статут чи наказ держави, що тримає в полоні, визначає дії, учинені військовополоненим, як карані, зокрема й відмову від залучення до робіт, тоді як такі самі дії не були б караними, якби 
їх здійснила особа зі складу військ держави, що тримає в полоні, то такі дії спричиняють лише дисциплінарні стягнення [9, с. 82].

Відповідно до ст. 6 Положення про закони і звичаї війни на суходолі Додатку до IV Гаагської Конвенції держава може, навіть, використовувати працю військовополонених, за винятком офіцерів, відповідно до їхнього чину і здібностей. Завдання не мають бути надмірними та не мають бути пов'язані з військовими діями. Військовополоненим може надаватися право працювати на державній службі, на приватних осіб або особисто для себе [11, с. 6]. Зауважимо, що цей аспект правового регулювання утримання військовополонених є окремим об'єктом дослідження.

Правовою гарантією для захоплених у полон осіб є те, що згідно 3 конвенційними вимогами після закінчення перебування їx у полоні внаслідок звільнення або їхньої репатріації, держава, що тримає в полоні, має видати їм документ, підписаний уповноваженим на те офіцером цієї держави, iз зазначенням кредитного сальдо, яке належить військовополоненому на той час. Крім цього, держава, що тримає в полоні, також надсилає через державу-покровительку уряду, від якого залежать військовополонені (уряду України), списки, що містять усі належні дані про всіх військовополонених, перебування яких у полоні закінчилося через репатріацію, звільнення, утечу або смерть чи в будь-який інший спосіб, зазначивши розмір їхнього кредитного сальдо. Будь-яке із зазначених вище положень цієї статті може бути змінене за взаємною згодою будь-яких двох сторін конфлікту. Саме держава, від якої залежить військовополонений, а це є Україна, несе відповідальність за врегулювання з ним кредитного сальдо, яке йому належить від держави, що тримала в полоні, після закінчення строку його перебування в полоні [9, с. 66].

Висновки. 3 огляду на зміст норм міжнародного гуманітарного права, за якими захоплення в полон під час воєнних дій не вважається протиправними діями, а лише правом збройних сил сторони, яка перебуває у збройному конфлікті, незаконним затриманням (захопленням) може вважатися лише захоплення цивільних осіб, які через це можуть набути статус «цивільний заручник» (у разі захоплення їх не через перебування в складі Збройних сил України).

За захопленими комбатантами України, як осіб, які зі зброєю беруть (брали) безпосередню участь у виконанні бойових завдань при захисті державного суверенітету, територіальної цілісності, демократичного конституційного ладу та інших національних інтересів України в складі військових формувань, добровольчих формувань комбатантів України, які перебувають під командуванням особи, відповідальної за поведінку своїх підлеглих та підпорядковані внутрішній дисциплінарній системі, яка забезпечує додержання норм міжнародного права та вимог чинного законодавства України, застосованих у період збройних конфліктів, має визнаватися та визначатися статус «військовополонені».

Не дотримуючись зазначених принципів i норм міжнародного гуманітарного права, згоду на обов’язковість яких надала Україна, держава сама не визнає сам факт існування міжнародного збройного конфлікту в ситуації на Сході України та законне перебування осіб зі зброєю у складі 
військових формувань і добровольчих формувань комбатантів України в цьому конфлікті, що має принципове значення для всіх вищезгаданих категорій осіб, зокрема й захоплених (військовополонених, заручників та інших незаконно позбавлених особистої свободи тощо) і 3 морального погляду, і з правового.

Але в будь-якому разі цивільні особи й комбатанти залишаються під захистом і дією принципів міжнародного права, що випливають 3 усталених звичаїв, $з$ принципів гуманності та 3 вимог суспільної свідомості [12, с. 1].

Навіть більше, Україна, як і інші держави-учасники угод 3 міжнародного гуманітарного права, зобов'язана піклуватися та ефективно захищати всіх людей, які вимушено опинилися під владою іншої сторони збройного конфлікту, як і тих, які опинились у військовому полоні, так і тих, кого було незаконно позбавлено особистої свободи внаслідок дій незаконних збройних формувань та/або органів влади Російської Федерації на окремих територіях Донецької та Луганської областей, де органи державної влади тимчасово не здійснюють свої повноваження, та тимчасово окупованій території України, а також соціально підтримувати їх після звільнення.

Але, як убачається, такі ефективні захист та піклування не можливе передусім з огляду на невизнання Україною за зазначеними особами статусу «військовополоненого» у розумінні ст. 4 ІІІ Женевської конвенції як осіб, які потрапили в полон до супротивника й належать до особового складу збройних сил сторони конфлікту (об'єднаних сил), членів ополчення або добровольчих загонів комбатантів України, які під час безпосередньої участі в антитерористичній операції, у заходах із забезпечення національної безпеки і оборони, відсічі і стримування збройної агресії РФ у Донецькій та Луганській областях виконують/виконували бойові завдання у взаємодії зі Збройними силами України, Міністерством внутрішніх справ України, Національною поліцією, Національною гвардією України й іншими утвореними відповідно до законів України військовими формуваннями та правоохоронними органами [9, с. 4], та незакріплення зазначеного статусу в нормативно-правових актах України, що приймалися через події на їі сході.

Для усунення невідповідності норм національного та міжнародного гуманітарного права, абзац 7 преамбули Закону України «Про особливості державної політики із забезпечення державного суверенітету України на тимчасово окупованих територіях Донецької та Луганської областях» від 18.01.2018 № 2268-VIII убачається доцільним доповнити посиланням на III Женевську конвенцію про поводження з військовополоненими від 12 серпня 1949 року.

Пункт 1 ст. 5 зазначеного Закону пропонується викласти в такій редакції: «1) уживають заходів для належного поводження при утриманні військовополонених, а також їх звільнення або репатріацію, зокрема в нейтральну країну, захисту прав і свобод цивільного населення, яке знаходяться під владою супротивної сторони збройного конфлікту, відповідно до норм міжнародного права».

Видається доцільним у всіх редакціях нормативно-правових актів України, що діють та їх проектах, які приймалися чи будуть прийматися 
через збройний конфлікт на Сході України, що стосуються питань правового і соціального захисту, соціальної підтримки осіб, які відповідно до норм міжнародного гуманітарного права визнаються жертвами війни, передбачити статус «військовополоненого» для всіх осіб, захоплених у полон під час бойових дій зазначеного конфлікту.

\section{Використані джерела:}

1. Звіт управління ООН з координації гуманітарних питань (UNOCHA). URL: https://twitter.com/OCHA_Ukraine/status (дата звернення: 12.02.2019).

2. URL:https:/ / tyzhden.ua/News/183366;//www.pravda.com.ua/news/2018 /12/16/7201383; / / uk.wikipedia.org/wiki. (дата звернення: 12.02.2019).

3. Про боротьбу з тероризмом : закон України від 20.03.2003 № 638-IV. Відомості Верховної Ради Украйни. 2003. № 25. Ст. 180 . URL: http:/ / zakon3.rada.gov.ua/laws/show/638-15_(дата звернення: 12.02.2019).

4. Про особливості державної політики із забезпечення державного суверенітету України на тимчасово окупованих територіях Донецької та Луганської областях : закон України від 18.01.2018 № 2268-VIII. Відомості Верховної Ради. 2018. № 10. Ст. 54. URL: http:/ / zakon5.rada.gov.ua/laws/show/2268-19 (дата звернення: 12.02.2019).

5. Деякі питання соціальної підтримки осіб, яких було незаконно позбавлено особистої свободи : постанова Кабінету Міністрів України від 31.01.2018 № 38. URL: http:/ / zakon0.rada.gov.ua (дата звернення: 12.02.2019).

6. Про правовий статус і соціальні гарантії осіб, які незаконно позбавлені волі, заручники, або засуджені на тимчасово окупованих територіях України та за іiі межами:проект закону України від 27.03.2018 № 8205. URL: http:/ /w1.c1.rada.gov.ua/pls/zweb2 (дата звернення: 23.02.2019).

7. Конституція України : закон України від 28.06.1996 №354к/96-ВР. Відомості Верховної Ради України. 1996. №30. Ст. 141. URL: http://zakon2.rada .gov.ua/laws/show/254к/96-вр (дата звернення: 12.02.2019).

8. Про міжнародні договори України : закон України від 29.06.2004 № 1906IV. Відомості Верховної Ради України. 2004. №50. Ст. 540. URL: https:/ / zakon.rada.gov.ua/laws/show/1906-15 (дата звернення: 12.02.2019).

9. III Женевська конвенція про поводження 3 військовополоненими : міжнародна конвенція від 12.08 .1949 / ратифіковано Україною 03.07.1954 / у редакції від 08.02.2006 згідно із законом України № 3413-IV. URL : http:/ / zakon.rada.gov.ua/laws (дата звернення: 12.02.2019).

10. IV Женевська конвенція про захист цивільного населення під час війни : міжнародна конвенція від 12.08.1949 / ратифіковано Україною 03.07.1954 / у редакції від 08.02.2006 згідно із законом України № 3413-IV. URL : https:/ / zakon.rada.gov.ua/laws/show (дата звернення: 12.02.2019).

11. IV Гаазька конвенція про закони і звичаї війни на суходолі та додатка до неї : міжнародна конвенція від 18.10.1907 / набрання чинності для України: 24.08.1991. URL: https:/ / zakon.rada.gov.ua/laws/show (дата звернення: 12.02.2019).

12. Додатковий протокол до Женевських конвенцій від 12.08.1949, що стосується захисту жертв міжнародних збройних конфліктів (Протокол I), від 08.06.1977. URL: https:/ / zakon.rada.gov.ua/laws (дата звернення: 12.02.2019).

13. Динис Г. Сучасні гібридні збройні конфлікти: правові аспекти / приклад агресії Російської Федерації проти України. URL: https://westudents.com.ua/ glavy/61571-11 (дата звернення: 12.02.2019). 
14. Кримінальний кодекс України : закон України від 05.04.2001 № 2341III. Відомості Верховної Ради Украйни. 2001. № 25-26. Ст. 131. URL: https:/ / zakon.rada.gov.ua/laws/ show/2341-14 (дата звернення: 12.02.2019).

Стаття надіӥшла до редколегї 20.02.2019

Кравченко И.Н., кандидат юридических наук, доцент, доцент кафедры государственно-правовых дисциплин Луганского государственного университета внутренних дел имени Э. А. Дидоренко (г. Северодонецк, Украина)

Правовые аспекты определения статуса военнопленного в связи с проведением Украиной операции Объединенных Сил (АТО) по обеспечению национальной безопасности и обороны, отражения и сдерживания вооруженной агрессии РФ в Донецкой и Луганской областях

В статье дана международно-правовая характеристика понятий «комбатант», «некомбатант», «гражданское лицо», «жертвы войны», «военнопленный», «гражданский заложник» в понимании норм международного гуманитарного права, их сравнительная характеристика с понятием физических лиц, которые находясь на законных основаниях на территории Украины, были захвачены в заложники или были в другой способ незаконно лишены свободы, который применяется в законодательстве Украины. Изучен вопрос необходимости нормативного закрепления понятия «военнопленный» в нормативно-правовых актах Украины в контексте проведения операции Объединенных Сил (АТО) по обеспечению национальной безопасности и обороны на востоке Украины.

Ключевые слова: вооруженный конфликт, гибридная война, комбатант, некомбатант, гражданское лицо, жертвы войны, военнопленный, гражданский заложник, антитеррористическая операция (АТО), операция Объединенных Сил.

Kravchenko I. Legal aspects of POW Status Determination of the Conduct of Ukraine's Joint Forces Operation (ATO) in Ensuring National Security and Defense, the Repulsion and the Containment of RF Armed Aggression in Donetsk and Luhansk Regions

The article contains an international legal description of the definitions combatant, non-combatant, a civilian, a casualty of war, POW, a civilian hostage in the understanding of international humanitarian law norms, their comparative characteristics with the concept of natural persons who while being lawfully present in the territory of Ukraine were taken hostage or unlawfully deprived of their liberty in any other way applied in Ukrainian legislation. The need of the statutory determination of the definition "prisoner of war» in Ukrainian legal and regulatory instruments in the context of Ukraine's Joint Forces Operation (ATO) in ensuring national security and defense in the eastern part of Ukraine has been explored. It is noted that the definitions "war" and "armed conflict" are decisive in POW status determination, but it is not principal if they are "hybrid" or "traditional", under direct or indirect armed aggression, and it is therefore not determinative.

Criteria facilitating to strengthen the protection of the civilian population against the effects of hostilities, because of combatants' obligations to differentiate themselves from a civilian population, namely to be commanded by a person responsible for his subordinates, to have a specified and identified sign clearly visible from afar, to carry weapons visibly, to act in accordance with the laws and customs of war etc., has been set out.

The principle of international humanitarian law according to which a capture during the military operations is not considered to be an illegal act, but only the right of the Armed 
Force to an armed conflict has been defined. The principle of humanity in treatment of prisoners of war, namely to avoid the discrimination based on race, skin color, religion or belief, gender, origin or property status or any other similar criteria has been disclosed.

The subjects entitled to prisoner of war status have been defined. Legal aspects of POW rights have been considered. International standards in treatment of this category of persons, namely hygiene and medical aid, discipline, use of the labor and wage, money, communication with the outside world, relations between them and authorities, the imposition of criminal and discipline sanctions, the release and direct repatriation after the cessation of hostilities have been accentuated. The need to strengthen penalties for violations of POW rights has been indicated.

Key words: armed conflict, hybrid war, combatant, non-combatant, a civilian, casualties of war, a prisoner of war, a civilian hostage, Anti-Terrorist Operation (ATO), Joint Forces Operation (JFO).

УДК 343.375 (477)

Крайник Г. С. кандидат юридичних наук, асистент кафедри кримінального права №1 Національного юоридичного університету імені Ярослава Мудрого (м. Харків, Україна)

Заточна В.О.

студентка 3 курсу Інституту прокуратури та кримінальної юстиції Національного юридичного університету імені Ярослава Мудрого (м. Харків, Україна)

\section{ПРОБЛЕМНІ ПИТАННЯ КРИМІНАЛЬНОЇ ВІДПОВІДАЛЬНОСТІ ЗА ЛЕГАЛІЗАЦІЮ (ВІДМИВАННЯ) ДОХОДІВ, ОДЕРЖАНИХ У ЗЛОЧИННИЙ СПОСІБ}

У статті висвітлено об'єктивну сторону складу злочину, передбаченого ч. 1 ст. 209 Кримінального кодексу України, а також п. 1 примітки до ст. 209 Кримінального кодексу. Розглянуто законодавче регулювання протидії легалізації доходів, одержаних у злочинний спосіб, запропоновано внести зміни до законодавства України в цій сфері. Приділено увагу невідповідності п. 1 примітки ст. 209 Кримінального кодексу України Конвенщії Ради Свропи про відмивання, пошук, арешт та конфіскацію доходів, одержаних у злочинний спосіб, та про фінансування тероризму. Запропоновано внести зміни до п. 1 ст. 209 Кримінального кодексу. Також розглянуто таку ознаку суб'єктивної сторони цього злочину, як мета. 3'ясовано, що це факультативна ознака суб'єктивної сторони, незважаючи на пояснення Пленуму Верховного Суду України.

Ключові слова: доходи, одержані в злочинний спосіб, легалізація (відмивання) доходів, протидія відмиванню доходів, предикатний злочин, фінансування тероризму.

Постановка проблеми. Економічне зростання сучасного суспільства нерозривно пов'язане із запобіганням різноманітним загрозам, що набувають особливого поширення в період реформування економічної системи. Проблема легалізації злочинних доходів перетворилася за останні (с) Крайник Г.С., 